TITLE:

\title{
A NEW SPECIES OF THE FIBULARIID SEA-URCHIN, FIBULARIA JAPONICA, FROM JAPANESE WATERS
}

\section{AUTHOR(S):}

Shigei, Michio

\section{CITATION:}

Shigei, Michio. A NEW SPECIES OF THE FIBULARIID SEA-URCHIN, FIBULARIA JAPONICA, FROM JAPANESE WATERS. PUBLICATIONS OF THE SETO MARINE BIOLOGICAL LABORATORY 1982, 27(1-3): 11-16

ISSUE DATE:

1982-03-30

URL:

http://hdl.handle.net/2433/176047

RIGHT: 


\title{
A NEW SPECIES OF THE FIBULARIID SEA-URCHIN, FIBULARIA JAPONICA, FROM JAPANESE WATERS
}

\author{
Mrghio SHIGEI \\ Misaki Marine Biological Station, Faculty of Science, Tokyo University
}

With Text-figures $1-48$

In the echinoid collections of the Misaki Marine Biological Station and the National Science Museum, I found a large number of small sea-urchin specimens belonging to a new species of the genus Fibularia. The rich materials obtained from various localities indicate that the new species occurs commonly in Japanese waters. It is certain that this species has been confused with Fibulariella acuta (Yoshiwara) because of its resembrance to the latter in its size (very small) and colour (white) (Ohshima, 1927, 1949; Utinomi, 1954, 1965; Nishiyama, 1966; Shigei, 1973).

I previously reported the occurrences of Fibularia n. sp. (Species No. 88) in western Japan and Sagami Bay in my earlier paper (Shigei, 1981). One of the purposes of the present paper is to describe it systematically.

Order Clypeasteroida A. Agassiz, 1872

Suborder Laganina Mortensen, 1948

Family Fibulariidae Gray, 1855

Genus Fibularia Lamarck, 1816

\section{Fibularia japonica sp. nov.}

Material examined.

The Misaki Marine Biological Station (MMBS) Collection Series:

Fib. Nos. 1-9 (No. 1, holotype): off MMBS, Sagami Bay; sublittoral zone; K. Aoki, J. Deguchi, T. Sekimoto, H. Suzuki and M. Shigei; 1926-1978.

Fib. No. 10: $3 \mathrm{~km}$ off Futamachiya $\left(35^{\circ} 08.5^{\prime} \mathrm{N}, 139^{\circ} 35.0^{\prime} \mathrm{E}\right)$, Sagami Bay; ca. $70 \mathrm{~m}$ depth; H. Suzuki, M. Sekimoto, K. Shimazaki and M. Shigei; July 4, 1979.

Fib. Nos. 11-14: east of Iki Island $\left(33^{\circ} 45.1^{\prime} \mathrm{N}, 129^{\circ} 57.5^{\prime} \mathrm{E}\right) ; 45 \mathrm{~m}$ depth; K. Oyama; July 31, 1973.

Fib. Nos. 15-19: off Tomioka (Amakusa), W. Kyushu; ca. $30 \mathrm{~m}$ depth; T. Kikuchi; Feb. 14, 1963.

Fib. Nos. 20-21: off Oki Islands (between Dogo and Dozen); ca. $60 \mathrm{~m}$ depth;

Publ. Seto Mar. Biol. Lab., XXVII (1/3), 11-16, 1982.

(Article 2) 
M. Ohuji; July 8, 1977.

The National Science Museum (NSM) Collection Series:

(A): Sagami Bay, sublittoral zone; twenty-seven specimens.

(B): Sagami Bay, sublittoral zone; three specimens.

(C): Suruga Bay, sublittoral zone; one specimen; Y. Okada.

(D): off Boso Peninsula $\left(34^{\circ} 51.2^{\prime} \mathrm{N}, 139^{\circ} 55.6^{\prime} \mathrm{E} ; 34^{\circ} 51.1^{\prime} \mathrm{N}, 139^{\circ} 55.2^{\prime} \mathrm{E}\right) ; 100 \mathrm{~m}$ depth; two specimens; Sep. 25, 1976; M. Imajima.

Diagnosis. Test ovoid, not pointed at either end. Pores of petals distinctly large, not forming regular petals. Only 2-3 pore-pairs in each series of petals. Hydropores in a groove. Ophiocephalous pedicellariae with elongate valves.

Description.. Small forms; $5.9(\mathrm{l}) \times 4.7(\mathrm{w}) \times 3.1(\mathrm{~h}) \mathrm{mm}$ in the holotype and $9.9(\mathrm{l}) \times$ $7.1(\mathrm{w}) \times 6.3(\mathrm{~h}) \mathrm{mm}$ in the largest paratype. The test is moderately valuted, not globular but rather low; the oral side is not deeply sunken; the outline is round to slightly elliptical or may be somewhat truncated posteriorly. There is no internal radiating partition wall. The pores of petals are round and large; they are arranged rather irregularly and do not form typical petals. Each pore-series of petals consists of only 2-3 pore-pairs in adult specimens, while $4-5$ in young specimens. The interporiferous zone is not elevated, and the pores of the small accessory tubefeet are discernible. The apical system is at the center or slightly anterior part of the test; hydropores are in a longitudinal furrow; genital pores are as large as or a little larger than the pores of the petals. The peristome is round or slightly rounded-pentagonal; the peristomial membrane is wholly naked. The periproct is round, much smaller than the peristome, covered by five, large; naked, radiating plates. The primary spines are simply pointed or somewhat truncated distally; the miliary spines are widened distally; the shaft of spines is finely thorny. The ophiocephalous pedicellariae are very few; their valves are elongate and the blades are distinctly serrated. The other types of the pedicellariae are lacking. The tubefeet have no sucking disk. The colour is in general pure white to the naked eye, however, purplish granules scattered on the skin of the test are discernible under the microscope.

Remarks. The present species is scarcely related to Fibulariella acuta (Yoshiwara) with which it has been confused. The latter species decidedly differs from the fomer in the following points (Yoshiwara, 1898, 1907; Tokunaga, 1903, 1906; H.L. Clark, 1914; Mortensen, 1948a-c):

The test distinctly pointed at both ends; the buccal membrance containing plates; the periproct being covered by small irregular plates; the tubefeet containig a calcareous disk; globiferous pedicellariae present; and ophiocephalous pedicellariae lacking.

In the genus Fibularia, the following species can easily be distinguished from the present species (the key characters are shown in parenthesis):

F. nutriens H.L. Clark, 1909 (petals absent); F. volva L. Agassiz, 1841 (the test elongate-oval and distinctly pointed at both ends); F. plateia H.L. Glark, 1928 (the hydropores not in a groove); $F$. cribellum Meijere, 1902 (the test flattened and the 


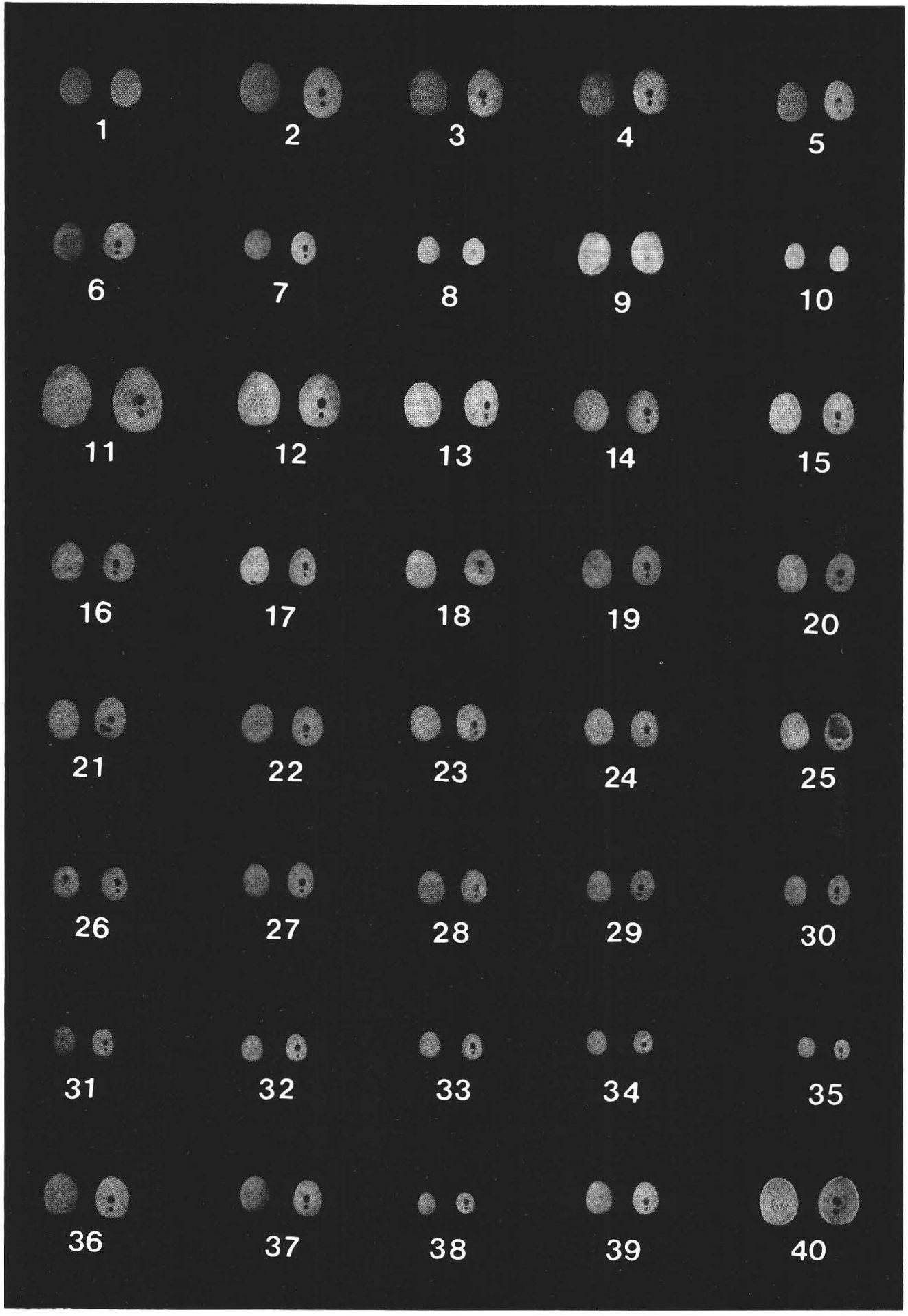

Fig. 1-40. Fibularia japonica sp. nov. in natural size. Aboral view (left) and oral view (right) are shown in each figure.

1, MMBS-Fib. No. 1 (holotype); 2-8, MMBS-Fib. Nos. 2-8; 9, MMBS-Fib. No. 10; 10, MMBS-Fib. No. 15; 11-35, NSM (A); 36-38, NSM (B); 39, NSM (C): 40, NSM (A) (internal view). 


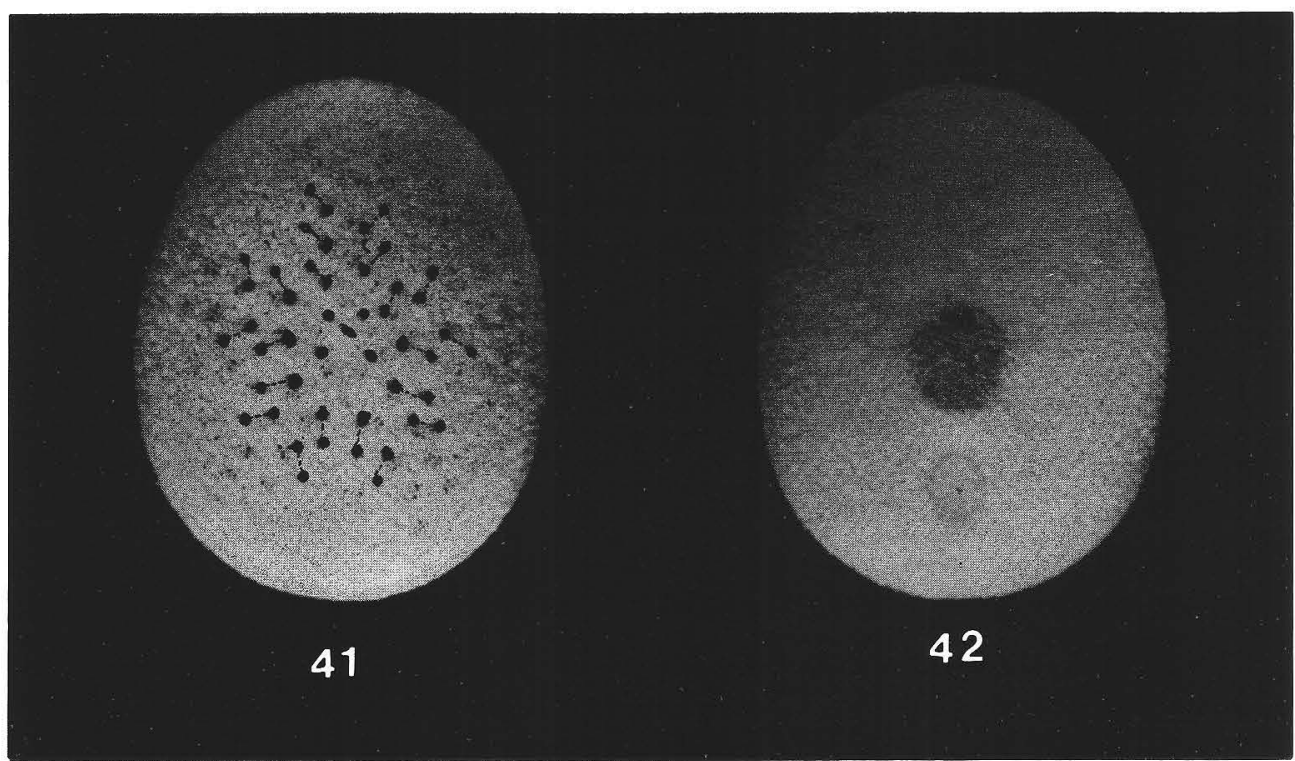

Fig. 41-42. Enlarged views of the holotype $(\times 9)$. 41, aboral view (modified). Dotted lines are drawn on the photo in order to show the relations of pores of petals. 42, oral view.

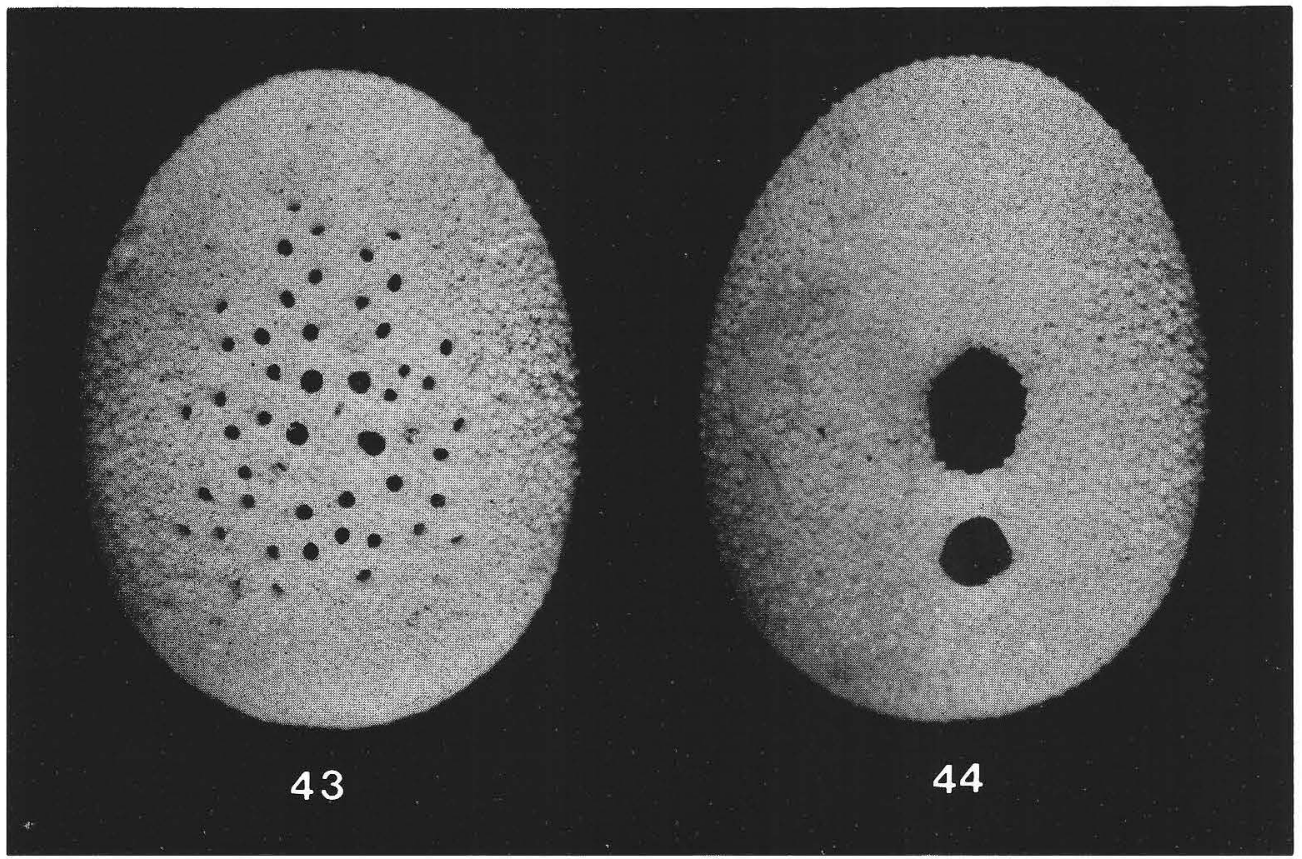

Fig. 43-44. Enlarged views of a paratype (MMBS-Fib. No. 2). 43 , aboral view. 44, oral view. 

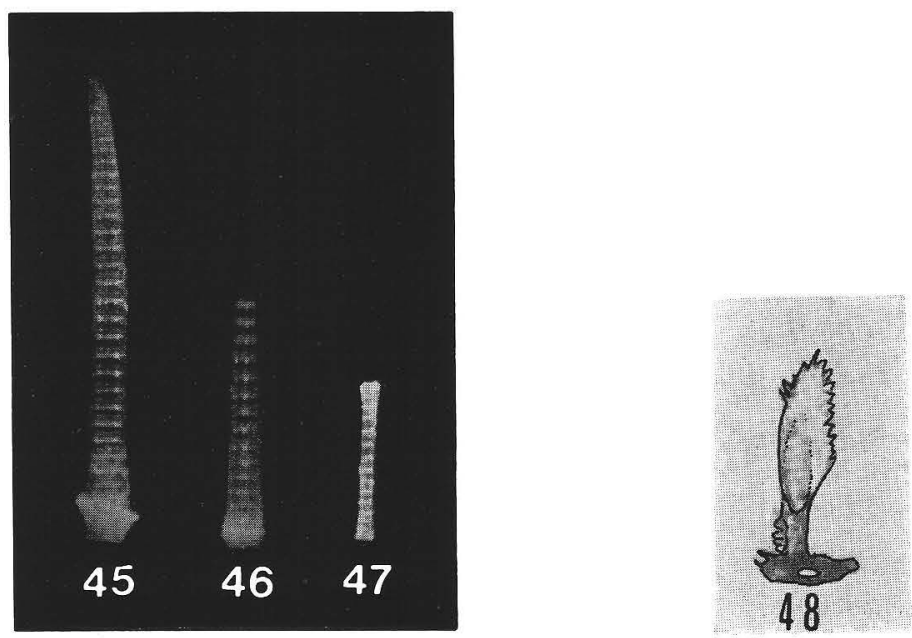

Fig. 45-47. Spines $(\times 60)$

45, a larger primary spine. 46 , a smaller primary spine. 47 , a secondary spine.

Fig. 48. A valve of the ophiocephalous pedicellaria $(\times 240)$.

pores of petals exceedingly large, continuing nearly to the edge of the test).

Among all the known species of Fibularia, $F$. ovulum Lamarck, 1816 may be most closely related to the present species, however, it is also clearly distinguished from the latter in the following points: the test is globular, scarcely flattened; and its posterior end never truncated; pores of the petals are small; each pore-series of petals consists of 4-6 pore-pairs and they form regular petals.

$F$. trigona Lamarck, 1816 seems to be merely a synonym or a variety of $F$. ovulum, however, the specimen which was collected from the Korea Strait and figured by Mortensen (1948c) under the name of $F$. ovulum trigona Lamarck probably does not belong to $F$. ovulum but belongs to the present species.

\section{Acknowledgements}

I wish to express my gratitude to Dr. Tadashige Habe of the former director of the Department of Zoology of the National Science Museum for his kindness in sending me a large number of fibulariid specimens for this study.

I am also indebted to the following Drs. who placed their valuable specimens at my disposal: Masami Ohuji of the Department of Biology, Shimane University; Minoru Imajima of the Department of Zoology, National Science Museum; and Taiji Kikuchi of the Amakusa Marine Biological Laboratory, Kyushu University.

\section{REFERENCES}

Agassiz, L. and P.J.E. Desor. 1847. Catalogue raisonné des espèces, des genres, et des families d'echinides. Ann. Sci. Nat., ser. 3, Zool., 7: 142. 
Clark, H.L. 1909. Scientific results of the trawling expedition of H.M.C.S. "Thetis" off the coast of New South Wales, in February and March 1898: Echinodermata. Australian Museum Mem. 4, pt. 11 : 557, pl. 58(1-11).

1914. Hawaiian and other Pacific Echini: the Cylpeasterina; the Clypeasteridae, Arachnoididae, Laganidae, Fibulariidae, and Scutellidae. Mem. Mus. Comp. Zool., 46: 58, pl. 126 $(1-4)$.

1928. The sea lilies, sea stars, and sea urchins of the South Australian Museum. Rec. South Australian Mus., 3(4): 477.

Lamarck, J.B. 1816. Historre naturelle des animaux sans vertebres. 3: 17.

Meijere, J.C.H. 1903. Vorlaufige Beschreibung der neuen, durch die Siboga-Expedition gesammelten Echiniden. Tjidschr. d. Nederland. Dierk. Vereen, ser. 2, 8(1): 7.

Mortensen, Th. 1948a. New Echinoidea (Cassiduloida, Clypeasteroida), preliminary notice. Vidensk. Meddel. Dansk. Naturhist. Foren., Kobenhavn, 111: 6.

1948b. Report on the Echinoidea collected by the United States Fisheries Steamer "Albatross" during the Philippine Expedition, 1907-1910: part 3, The Echinoneidae, Echinolampadidae, Clypeasteridae, Arachnoididae, Laganidae, Fibulariidae, Urechinidae, Echinocorythidae, Palaeostomatidae, Micrasteridae, Palaeopneustidae, Hemiasteridae, and Spatangidae. U.S. Nat. Mus., Bull. 100, 14: 109.

1948c. A monograph of the Echinoidea, 4(2), Clypeasteroida: Clypeasteridae, Arachnoididae, Fibulariidae, Laganidae, and Scutellidae; 203-225, pls. 46, 69.

Nishiyama, S. 1966. The echinoid fauna from Japan and adjacent regions, part 2. Palaeont. Soc. Japan, Spec. pap., 13: 373.

Ohshima, H. 1927. Echinoidea. In illustrated encyclopedia of the fauna of Japan: 1825, fig. 3481 (in Japanese).

1949. ibid. (revised ed.): 581, fig. 1682 (in Japanese).

Shigei, M. 1973. A check list of echinoids found in Sagami Bay with brief notes on each species. J. Fac. Sci., Univ. Tokyo, ser. 4, 13:21.

1981. A study on the echinoid fauna of the East China Sea and the coastal waters of Southern Korea, Kyushu, Ryukyu and Taiwan. Publ. Seto Mar. Biol. Lab., 26(1/3): 202.

Tokunaga, S. 1903. Fossil echinoids of Japan. J. Coll. Sci. Tokyo, 17: 7, pl. 2(5-6).

1906. Fossils from the environs of Tokyo. ibid., $21: 71$.

Utinomi, H. 1954. A check list of echinoids found in the Kii region. Publ. Seto Mar. Biol. Lab., 3: 353

1965. Echinoidea. In illustrated encyclopedia of the fauna of Japan, 3: 78, fig. 244 (in Japanese).

Yoshiwara, S. 1898. Preliminary notice of new Japanese echinoids. Annnt. Zool. Japon., 2: 60. 1907. Japanese Echini (plates). Zool. Mag., 19: pl. 14(3-4). 